\title{
Intertekstualność, dialogowość i przytoczeniowa budowa utworu literackiego
}

Aleksandra Okopień-Sławińska

TEKSTY DRUGIE 2020, NR 5, S. 37-52

DOI: 10.18318/td.2020.5.4

\section{Zdzistawowi Łapińskiemu - memu przyjacielowi od przeszło pót wieku - ten przeszło trzydziestoletni tekst poświęcam z wdzięcznością}

$\mathbf{T}$ o najpewniej duch czasu spowodował, że Intertekstualność i dialogowość (lub: dialogiczność) znalazły się naraz w polu zainteresowań badaczy. Dwa te pojęcia, będące hasłami wywoławczymi dla współczesnych sposobów myślenia o uczestnictwie pojedynczego wytworu słownego (wypowiedzi, tekstu, dzieła) w całym uniwersum takich wytworów, pozostają ze sobą w niewątpliwych, lecz nie dość jasnych relacjach. Chociaż łączą je nici, a nawet więzy pokrewieństwa (jak np. inspiracja Bachtinowska w pracach francuskich semiologów) i oczywiste podobieństwo problematyki, to jednak studia nad nimi toczą się po oddzielnych i niezbieżnych torach, nie wchodzą w kolizje, ale się też nie sumują. Intertekstualność i dialogiczność pozostają w orbicie odrębnych orientacji teoretycznych i tradycji filozoficznych i tylko

\section{Aleksandra}

Okopień-

-Sławińska - (ur.

1932), em. prof. dr hab.

Zajmuje się teorią

literatury, semantyką

poetycką, wersyfi-

kacją, sztuką rozu-

mienia tekstu oraz

sprawami kształcenia

polonistów. Autorka

szeregu publikacji,

m.in. książek Wiersz

nieregularny i wolny

Mickiewicza, Stowac-

kiego i Norwida (1964)

oraz Semantyka

wypowiedzi poetyckiej

(1985, 1998, 2001),

współautorka pod-

ręcznika Zarys teorii literatury oraz Słownika terminów literackich.

Pracowała w gdańskiej WSP (1960-63),

na UW ((1955-71), w warszawskiej PWST (1978-94) oraz W IBL PAN (1971-2002). 
jeśli pełnią funkcję przygodnych narzędzi interpretacyjnych, stosowane bywają równocześnie, a nawet wymiennie.

Zarówno jedno, jak i drugie z tych pojęć, skoro tylko staje się ośrodkiem teoretycznych medytacji, objawia uniwersalną podatność zastosowawczą do wszelkich tworów słownych, od wypowiedzi potocznych po dzieła myśli i sztuki. Wszystkie one bowiem - zależnie od nastawienia badacza - okazywać się mogą zjawiskami intertekstualnymi bądź dialogowymi: przemieniać w sploty wielotekstowe albo rozbrzmiewać wielością różnych głosów. Oba nastawienia, mimo dzielących je różnic, upodabnia bowiem idea udziału każdej nowo powstającej wypowiedzi w wielkiej społeczności innych wypowiedzi, w powiązaniu z którymi ta nowa formuje swą postać, uzyskuje znaczenie i może w ogóle zaistnieć.

Idea taka odgrywa istotną rolę w postsaussur'owskiej reorientacji semiologicznej, postępującej wraz z rozwojem współczesnej lingwistyki wypowiedzi, zwanej też lingwistyką tekstu, a przez Bachtina - metalingwistyką. Przy intertekstualnej lub dialogicznej interpretacji wypowiedzi schodzi bowiem na plan dalszy fundamentalna dla dziedzictwa myśli de Saussure'a relacja: wypowiedź - system, pierwszoplanowa zaś staje się relacja: wypowiedź - inne wypowiedzi, a w innej terminologii: tekst - inne teksty. W konsekwencji jednostkowy gest stwórczy powołujący do życia nową wypowiedź przestaje być pojmowany jako indywidualne i swobodne spożytkowanie możliwości systemowych, dokonanie operacji wyboru i układu poszczególnych znaków pochodzących z powszechnego, a zatem niczyjego, repertuaru jednostek i reguł systemowych. Okazuje się on natomiast przede wszystkim aktem uczestnictwa w sferze dotychczasowych dokonań, wielorako przez sferę tę zdeterminowanym.

\section{$* * *$}

Zasięg tego zdeterminowania oraz odmiany więzi międzytekstowych stały się pierwszorzędnym przedmiotem zainteresowania francuskich semiologów. Ich dorobek w tym zakresie podsumowuje z nieprzeciętną inwencją terminologiczną książka Gerarda Genette'a'. Wyróżnił on pięć typów intertekstualności, czyli zewnątrztekstowych odniesień tekstu. A więc: 1. intertekstualność (obecność jednego tekstu w drugim, np. w postaci cytatu, aluzji itp.);

1 G. Genette Palimpsestes. La littérature au second degré, Éditions du Seuil, Paris 1982; o koncepcji Genette'a wspominał M. Głowiński w rozprawie O intertekstualności, „Pamiętnik Literacki” 1986 z. 4. 
2. paratekstualność (relację tekstu do tekstów bezpośrednio go uzupełniających, np. do tytułu, przedmowy, posłowia, komentarzy, ilustracji, obwoluty itp.); 3. metatekstualność (relację krytyczną między tekstami, z których jeden mówi o drugim); 4. hipertekstualność, czyli całość relacji łączących jakiś tekst późniejszy, hipertekst, z tekstem wcześniejszym, hipotekstem, na którym ten późniejszy się zasadza, stając się przez to tekstem drugiego stopnia; 5. architekstualność (relację ustalającą przynależności taksonomiczne tekstu, przyporządkowującą go pewnym klasom ogólnym, takim jak typy dyskursu, sposoby wypowiadania, gatunki literackie). Uwagę Genette'a przyciąga zwłaszcza hipertekstualność traktowana jako uniwersalny aspekt literackości. Twierdzi on, że nie ma dzieła literackiego, które jakoś nie odwoływałoby się do innego, przy czym teksty drugiego stopnia, hiperteksty, są bardziej literackie niż hipoteksty, jako że żyją z literatury.

Świadomość międzytekstowego zdeterminowania nie jest już jednakże odkryciem intertekstualistów. W tym samym 1969 roku, w którym Julia Kristeva wydała Semeiotiké, wprowadzając programowo nazwę i problematykę intertekstualności, Michel Foucault w Archeologii wiedzy przedstawił, przez późniejsze badania bynajmniej nie zdezaktualizowany, opis pola dyskursywnego, w relacji do którego sekwencja znaków językowych staje się wypowiedzią. Zakreślił przy tym i pobudzająco sproblematyzował cztery wymiary przestrzeni odniesień intertekstualnych, nie posługując się wszakże tym terminem:

Pole towarzyszące, które ze zdania lub z serii znaków czyni wypowiedź i które pozwala im mieć określony kontekst, zróżnicowaną treść przedstawieniową, tworzy sieć nader złożoną. Kształtuje je najpierw seria innych sformułowań, w obręb których wypowiedź wpisuje się, funkcjonując jako element (układ replik tworzący rozmowę, architektura dowodu zamknięta z jednej strony przesłankami, a z drugiej wnioskiem, szereg oznajmień budujących opowiadanie). Kształtuje je także zbiór sformułowań, do których wypowiedź się odwołuje (implicite lub explicite), bądź powtarzając je, bądź modyfikując je lub adaptując, bądź przeciwstawiając się im, bądź mówiąc o nich na nowo: nie ma wypowiedzi, która by w taki czy inny sposób nie reaktualizowała innych (elementów rytualnych w opowiadaniu, przyjętych wcześniej twierdzeń w dowodzie, zdań konwencjonalnych w rozmowie). Kształtuje je również zbiór sformułowań, którym wypowiedź stwarza możliwość istnienia w przyszłości i które mogą zjawić się po niej jako jej konsekwencja, jej naturalny skutek 
lub odpowiedź na nią (rozkaz nie otwiera takich samych możliwości wypowiedzeniowych jak twierdzenia jakiejś aksjomatyki czy początek opowiadania). Wreszcie, kształtuje je zbiór sformułowań, których status dana wypowiedź dzieli, pośród których zajmuje miejsce - ale nie w sensie układu linearnego, wraz z którymi zniknie lub przeciwnie - zostanie zwaloryzowana, zachowana, uświęcona oraz wskazana jako możliwy przedmiot przyszłemu dyskursowi (wypowiedź nie da się oddzielić od statusu, który otrzymuje jako „literatura”, jako nieistotne wyrażenie, co łatwo może pójść w niepamięć, jako prawda naukowa zdobyta na zawsze, jako słowo prorocze itd.) ${ }^{2}$

Zapewne opis przestrzeni odniesień międzytekstowych można by jeszcze zagęścićs , ale i tak jest on dość wypełniony, aby na różne sposoby uprzytamniać ogólne prawo semiotyczne mówiące - w uproszczeniu - że wypowiedź rodzi się z wypowiedzi. Jednakże im więcej relacji uczestniczących w tym akcie nauka odkrywa, im widoczniej rozszerza się zasięg intertekstualności, tym trudniejsze staje się jej zastosowanie jako dyrektywy interpretacyjnej przy rozpatrywaniu konkretnego tekstu. Identyfikacja jego intertekstualnych uwarunkowań staje się bowiem zadaniem nie do końca wykonalnym.

Najłatwiej uchwytne pozostają bezpośrednie związki międzytekstowe poświadczone obecnością różnorakich, mniej lub bardziej przetransformowanych i rozmaicie sfunkcjonalizowanych, zapożyczeń i podobieństw na różnych poziomach tekstu - a więc wielorakich śladów stylizacji, od cytatu do parodii.

Procedurom interpretacyjnym, wprawdzie wymagającym innego sproblematyzowania, poddają się również pośrednie związki międzytekstowe, o charakterze zmediatyzowanym. Dają się one ustalić przede wszystkim przez odniesienie do jakiejś wspólnej sfery, jakiegoś rozległego intertekstu, takiego jak gatunek mowy, styl epoki, konwencja poetycka, dyskurs w rozumieniu Foucaulta ${ }^{4}$. Inny mechanizm zmediatyzowanych relacji intertekstualnych

2 M. Foucault Archeologia wiedzy, przeł. A. Siemek, wstęp J. Topolski, PIW, Warszawa 1977, s. 129; pierwsze wydanie oryginalne: Archéologie du savoir, Gallimard, Paris 1969.

3 Np. o relacje intersemiotyczne wymienione w haśle Intertekstualność autorstwa J. Sławińskiego w: M. Głowiński, T. Kostkiewiczowa, A. Okopień-Sławińska, J. Sławiński Słownik terminów literackich, red. J. Sławiński, wydanie 2, Ossolineum, Wrocław 1988.

4 Jedna z najzwięźlejszych formuł definicyjnych dyskursu powiada, że jest to „zbiór wypowiedzi należących do jednego systemu formacyjnego" składających się np. na dyskurs kliniczny, dyskurs ekonomiczny, dyskurs historii naturalnej czy dyskurs psychiatryczny. M. Foucault Archeologia..., s. 140. 
przedstawił Michael Riffaterre, adaptując Peirce'owskie pojęcie interpretanta do analizy przekształceń pewnych topoidalnych konwencji poetyckiego obrazowania 5 .

Poza sferami bezpośrednich i pośrednich związków intertekstualnych rozciąga się jednakże sfera trzecia: bezgraniczna przestrzeń związków nierozpoznawalnych, anonimowych śladów, skutków oderwanych od przyczyn. One to, nie zaś widoczne na powierzchni inkrustacje tekstowe, tworzą głęboką intertekstualną tkankę wypowiedzi. One to, te wszystkie - jak je nazywa Roland Barthes - cytaty bezimienne i zniekształcone, kody niekompletne o zatartym, nieznanym początku, apelują do jakiegoś wcześniejszego doświadczenia tekstowego odbiorcy, doświadczenia ważnego, choć tak niewyraźnego, że zaledwie dającego się ująć formułą „ déjà lu" - ,już czytane”.

Poczucie obcowania z czymś znanym skądinąd pozostaje więc jedynym dostępnym świadectwem ukrytej intertekstualności. Mimo to, właśnie jej istnienie - nieuchwytne, ale i niepodważalne - kieruje myśl badaczy na rzeczywiście nowe tory. Nowe, gdyż wszelakie oczywiste związki międzytekstowe, choć nie poddane scalającej teorii intertekstualnej i przedstawiane w mniej lub bardziej przypadkowych układach, były wszakże od dawna przedmiotem namysłu przy opisie zjawisk stylizacji czy też przy studiach genologicznych, komparatystycznych, wpływologicznych. I jakkolwiek współczesne koncepcje tych związków wychodzą poza ramy tradycyjnej problematyzacji, to jednak prawdziwie nowe wyzwanie badawcze zrodziła dopiero świadomość intertekstualności bezgranicznej, niemożliwej do analitycznego opanowania.

Różne okazały się sposoby reakcji na to wyzwanie. Ten, który podsunęła praktyka Michela Foucaulta, polega na przesunięciu uwagi z intertekstualnej charakterystyki pojedynczej zindywidualizowanej wypowiedzi na charakterystykę wchłaniającego ją dyskursu, a więc zbioru wypowiedzi tworzącego poddaną określonym regularnościom i transformacjom całość.

Inną reakcją stał się zwrot zainteresowań od rozpoznawania pojedynczych odprysków intertekstualności w tekście ku objaśnianiu ogólnego mechanizmu funkcjonowania tego, co już powiedziane (intertekstu), w obrębie tego, co właśnie dopiero mówione (tekstu). Mechanizm ten sprzęgnięty został m.in. ze znanym semantyce logicznej zjawiskiem presupozycji, a więc

5 M. Riffaterre Semiotyka intertekstualna: interpretant, przeł. K. i J. Faliccy, "Pamiętnik Literacki” 1988 z. 1 (opublik. W 1979 roku).

6 R. Barthes S/Z, Éditions du Seuil, Paris 1970; oraz tegoż De l'œuvre au texte, „Revue d'Estetique” 1971. 
przekazywania pewnej części informacji zdaniowej jako niekwestionowalnej, implikowanej bowiem zarówno przez dane zdanie, jak i przez jego negację. Zawartość informacyjna presupozycji ma w wypowiedzi status tego, co znane, ustanawia więc wyjściową strefę porozumienia z odbiorcą. Jej zasięg można zatem potraktować jako zasięg intertekstualnej kompetencji wpisanej w tekst i przezeń zakładanej u odbiorcy. Badanie presupozycji jako tekstowego wskaźnika intertekstualności proponuje Jonathan Culler, twierdząc, że

problem interpretacji utworu staje się w gruncie rzeczy kwestią ustalenia, jaki stosunek przyjmuje dany utwór wobec wcześniejszej wypowiedzi, na którą wskazuje jako presuponowaną. [...] Presuponując pewne zdania, dzieło traktuje je jako wcześniejszą wypowiedź, jako część tradycji, w którą się wpisuje. Możemy wcale nie znaleźć we wcześniejszych utworach zdań podobnych do owych presuponowanych; nie ma to większego znaczenia. Funkcjonują one jako już czytane; każą się uznać za już czytane dzięki temu właśnie, że są presuponowane. ${ }^{7}$

Widząc w presupozycjach narzędzie zdatne do pomiaru intertekstualnego potencjału utworu, Culler dość swobodnie zagęszcza ich sieć, pisząc nie tylko o presupozycjach logicznych, ale także o presupozycjach pragmatycznych oraz lingwistycznych, retorycznych i literackich.

Wraz z uświadomieniem nieogarnionego zasięgu intertekstualności myślenie o niej zwróciło się jeszcze w jednym kierunku, a mianowicie ku jej funkcji uprawdopodobniającej tekst, oswajającej go, czyniącej zrozumiałym i zdolnym do znaczenia w przewidzianych dlań układach kulturowych. "Oswajanie tekstu polega na powiązaniu go z typem wypowiedzi lub z wzorcem, który jest już w jakimś sensie naturalny i czytelny" - to znowu Jonathan Culler, komentujący idee Barthes'a, Todorova, Kristevej, Genette'a i Genota ${ }^{8}$. Idee te, których wspólnym mianownikiem jest intertekstualna wykładnia pojęcia literackiej vraisemblance, prowadzą do gruntownego przeformułowania kryteriów mimetyczności sztuki: „prawdę” dzieła poświadcza nie odniesienie do świata, lecz odniesienie do ukształtowanego tekstowo i utrwalonego społecznie wyobrażenia o świecie. W ujęciu Cullera i innych takie „wyobrażenie

7 J. Culler Presupozycje i intertekstualność, przeł. K. Rosner, "Pamiętnik Literacki” 1980 z. 3, s. 308 (opublik. w 1976 roku).

8 J. Culler Konwencja i oswojenie, przeł. J. Sieradzki, w: ks. zb.: Znak, styl, konwencja, wyb. i wstęp M. Głowiński, Czytelnik, Warszawa 1977, s. 157 (opublik. w 1975 roku). 
o świecie" ma również naturę tekstową, podobnie jak to, co uważane bywa za „prawdziwe życie”, a także to wszystko, co składa się na „opinię publiczną". W ten sposób sfera intertekstualności bezmiernie się rozrasta poza przestrzeń relacji obejmujących wyraźnie ukształtowane wytwory słowne. Samo zaś to pojęcie zaczyna raczej służyć filozofii mowy czy też filozofii kultury niż być narzędziem interpretacji wypowiedzi, pozwalającym rozpoznać jej składniki, ich wiązania i całą budowę.

$* * *$

Podobną - jak intertekstualność - oscylację między narzędziem analizy tekstowej a kategorią filozoficznego dyskursu wykazuje pojęcie dialogowości. Podobnie jak intertekstualność tyczy się ono współobcowania i współzależności różnych wypowiedzi i traktowane jest jako relacja uniwersalna determinująca rozwój i sens wszystkich wytworów mowy. Podobnie wreszcie bywa egzemplifikowane. Wcale nierzadko tego samego rodzaju układy testowe są opisywane jako zawęźlenia intertekstualne lub dialogiczne. Obie takie kwalifikacje stosować się bowiem dają do odciśniętych w tekście śladów innych wypowiedzi czy - inaczej rzecz ujmując - do widocznych w wypowiedzi miejsc wspólnych, tj. dzielonych przez nią z jedną lub wieloma wypowiedziami, a więc do jawnych cytatów, przytoczeń, nawiązań, parafraz, aluzji, stylizacji, trawestacji, parodii itp.

Czy znaczy to więc, że intertekstualność i dialogiczność można utożsamić lub że dzieli je tylko jakaś różnica zakresów, a zatem można np. stwierdzić, że pierwsza jest pojęciem węższym niż druga, albo też spierać się, iż jest odwrotnie? Byłby to spór najzupełniej jałowy. Intertekstualność i dialogiczność nie różnią się zakresami, są bowiem pod tym względem nieporównywalne jako dwie głęboko, filozoficznie, odmienne koncepcje interpretacyjne wytworów mowy.

Kamieniem węgielnym ich odmienności jest kwestia wypowiadającego podmiotu. Bachtin czyni ją ośrodkiem dialogowej teorii wypowiedzi; w semiologii francuskiej natomiast odsuwana jest programowo poza horyzont tekstu. Szczególnie wyraźnie odsunięcie to nastąpiło wraz z rozwojem écriture przeciwstawianego mó wi en i u - pis a ni u, odrywającego, przez swą moc utrwalania i reprodukowania tekstu, komunikat znakowy od macierzystej sytuacji komunikacyjnej, wytwór od aktu stwórczego, dzieło od autora. Idea ta, która radykalny wyraz znalazła w pracach Jacques'a Derridy, przenika poglądy właściwie wszystkich intertekstualistów. 
Rolę podmiotu redukuje również, choć w inny sposób, Michel Foucault. Skoncentrowany na badaniu dyskursów, a więc zbiorów rzeczywistych wypowiedzi „w ich zdarzeniowym rozproszeniu i w jednostkowym zjawianiu się" z założenia wyklucza on zainteresowanie „tym, kto mówi”, stojącym na zewnątrz wypowiedzi. Poświęca natomiast uwagę podmiotowi uwewnętrznionemu, przyjmując, że jednym z czterech przejawów modalności wypowiedzi, które odróżniają ją od niebędącej wypowiedzią serii znaków, jest możliwość określenia jakiejś pozycji podmiotu.

Podmiot ów jest dlań jednak tylko „wymiarem charakteryzującym każde sformułowanie jako wypowiedź”, „zdeterminowanym i pustym miejscem, które może być w istocie wypełniane przez różne jednostki [, i które] miast być określone raz na zawsze i jako takie utrzymywać się na przestrzeni całego tekstu, książki, dzieła - zmienia się, a mówiąc dokładniej, zmienia się w ten sposób, że raz pozostaje takie samo w szeregu kolejnych zdań, innym razem z każdym [zdaniem - przyp. A.O.-S.] ulega modyfikacji”"10. Podmiotowa budowa tekstu ma w tym ujęciu wymiar linearny, a nie hierarchiczny, narasta i zmienia się w kolejnych, dowolnie długich seriach zdaniowych, które następczo i przemiennie formują różne konstrukcje podmiotowe, np. wpierw bohatera $\mathrm{X}$, potem narratora, potem bohatera $\mathrm{Y}$, znowu narratora itd.

Jest oczywiste, że na takim rozumieniu podmiotowości Bachtin nie mógłby oprzeć swej dialogowej koncepcji mowy. Zakłada ona bowiem hierarchiczne uporządkowanie relacji podmiotowych, a przede wszystkim ośrodkową rolę podmiotu w semantycznej organizacji wypowiedzi oraz jego komunikacyjną aktywność, zarówno realną, jak i przedstawioną w tekście czy też przezeń implikowaną. Według Bachtina stosunki dialogowe nie mogą się zawiązywać między „niczyimi” - tj. nie poddanymi czyjejś podmiotowości - jednostkami systemu językowego. Objawiają się natomiast i zawiązują w sferze wypowiedzi, a więc w sferze językowego obcowania ludzi, która ze swej istoty ma charakter dialogowy. Filozoficzne implikacje tego poglądu prowadzą Bachtina aż do stwierdzenia „dialogowej natury świadomości” i „dialogowego charakteru samego ludzkiego życia”.

"Jedyną adekwatną formą j ę z y k o w ej e k s p r e s j i prawdziwego życia człowieka jest n i e z w i e ń c z o ny di a log. Życie z istoty swej jest dialogowe. Żyć to uczestniczyć w dialogu: pytać, słuchać, ponosić odpowiedzialność, 
aprobować itp.” „Każda wypowiedź pełna jest ech i pogłosów innych wypowiedzi, z którymi uczestniczy we wspólnocie obcowania językowego w danej sferze. Każdą należy traktować przede wszystkim jako odpowiedź na wypowiedzi, które ją poprzedzały [...]: wypowiedź dementuje je, podtrzymuje, dopełnia, opiera się na nich, zakłada wiedzę o nich, w jakiś sposób liczy się z nimi" ${ }^{12}$.

Definiując stosunki dialogowe, Bachtin podkreśla, że „są to stosunki tak swoiste, że nie dadzą się sprowadzić ani do relacji logicznych, ani lingwistycznych, ani psychologicznych, ani mechanicznych, ani też jakichkolwiek innych naturalnych związków. Tworzą one odrębny rodzaj relacji z n a c z e n i o w y ch, a ich członami mogą być jedynie całe wypowiedzi (lub wypowiedzi rozpatrywane jako całe albo potencjalnie całe), za którymi kryją się (i w których się wy ra ż j ą) realne lub potencjalne podmioty mowy - autorzy danych wypowiedzi"13.

W przytoczonej definicji stosunków dialogowych Bachtin mówi, że zachodzą one między c ały $\mathrm{m}$ i wypowiedziami, natomiast w Problemach poetyki Dostojewskiego, gdzie dokonuje analiz tekstowych oraz szczegółowej systematyzacji tych związków, rozszerza zasięg dialogowości i powiada expressis verbis:

stosunki dialogowe są możliwe nie tylko pomiędzy względnie całymi wypowiedziami: dialogowe ujęcie jest możliwe wobec każdej znaczącej części wypowiedzi, a nawet wobec pojedynczego słowa, o ile odbieramy je nie jako bezosobowy wyraz języka w ogóle, lecz jako znamię cudzej pozycji myślowej, jako reprezentanta cudzej wypowiedzi - czyli: jeżeli słyszymy w nim cudzy głos. ${ }^{14}$

Nadto poza relacjami dialogowymi łączącymi wypowiedzi lub ich cząstki wymienia Bachtin możliwość jeszcze dwóch innych płaszczyzn powstawania

11 M. Bachtin Nad nowq wersją książki o Dostojewskim, w: Estetyka twórczości słownej, przeł. D. Ulicka, opr. przekładu i wstęp E. Czaplejewicz, Warszawa 1986, s. 453. To samo sformułowanie zwróciło uwagę H. Markiewicza (Polifonia, dialogiczność i dialektyka. Bachtinowska teoria powieści, „Pamiętnik Literacki” 1985 Z. 2, s. 91). M. Bachtin Problem gatunków mowy, w: Estetyka..., s. 390-391.

13 M. Bachtin Problem tekstu w lingwistyce, filologii i innych naukach humanistycznych, w: Estetyka..., s. 433 .

14 M. Bachtin Problemy poetyki Dostojewskiego, przeł. N. Modzelewska, PIW, Warszawa 1970, S. 279. 
takich relacji: między różnymi stylami słownymi czy dialektami środowiskowymi oraz między cząstkami mowy tego samego podmiotu, jednakże znowu tylko pod warunkiem, że dochodzi przy tym do zetknięcia dwóch różnych pozycji myślowych, światopoglądów, stanowisk czy opinii.

A zatem - podążając za myślą Bachtina - całościowość związanych dialogowo wypowiedzi można rozumieć nie - jako morfologiczną całościowość tekstową, lecz jako całościowość podmiotową, relacje dialogowe zaś pojmować jako relacje między myślowymi stanowiskami odrębnych podmiotów mowy. Z kolei za sprawdzian dialogowego nastawienia wypowiedzi można przyjmować nie empirycznie stwierdzalną w niej obecność elementów tekstowych znanych skądinąd, lecz zetknięcie, starcie, grę sensów mających różne podmiotowe odniesienia i znajdujących swoje znaczeniowe wykładniki w postaci odciśniętych w tekście śladów cudzego słowa. Przy takim ujęciu znika nierozwiązywalna inaczej trudność interpretacyjna, mająca źródło w tym, że każdy tekst - z natury swojej - jest budowany z elementów powtarzalnych, tak czy inaczej gdzieś już użytych.

\section{***:}

Przyjąwszy, że relacje dialogowe mają charakter podmiotowy, a ściślej: powstają w rezultacie zetknięcia się w mowie dwóch różnych podmiotowości, wypada zastanowić się systematyczniej nad warunkami ich realizowania w wypowiedziach. Istnieją, jak się w tej chwili, dość prowizorycznie, wydaje, trzy odmienne sytuacje komunikacyjne, w których zawiązują się relacje dialogowe. Są to sytuacje właściwe: 1. pojedynczej wypowiedzi monologowej, 2. wypowiedzi w dialogu, 3. wypowiedzi w wypowiedzi.

Ad 1. Bachtin uporczywie powtarzał, że każda wypowiedź jest naznaczona dialogowością, gdyż jakoś uczestniczy w ogólnym dialogu, jakim jest ludzkie słowne obcowanie. Z punktu widzenia komunikacyjnej teorii wypowiedzi dialogowość wypowiedzi wynika z samej zasady jej istnienia, stanowiącej, iż sekwencja znaków językowych staje się wypowiedzią, tylko jeśli poddana zostanie relacji nadawczo-odbiorczej, a więc jeśli ktoś użyje jej z intencją komunikacyjną. Obligatoryjność odbiorcy w tym akcie nie znaczy jego fizycznego istnienia, lecz znaczy, że mówiący - poprzez swoją wypowiedź - zakłada, a nawet projektuje, p od mi o t o w o ść odbiorcy. Właśnie podmiotowość, czyli zdolność stworzenia „wypowiedzi odpowiadającej”, będącej - co najmniej - milczącym lub jakoś zaznaczonym sygnałem m o żl i w o ś c i rozu mi eni a wypowiedzi doń kierowanej. 
Gdyby nie takie założenie podmiotowości odbioru, to równoprawnym adresatem mowy mógłby być kamień, a retoryczne apostrofy stwarzałyby taką samą sytuację komunikacyjną jak osobowe zwroty dialogowe. Nie potrzeba tu chyba wyjaśnień, iż rzeczywisty akt odbioru i zrealizowane w nim rozumienie mogą kreować inny od projektowanego podmiot odbiorczy. Podsumowując: minimalna dialogiczność właściwa jest każdej wypowiedzi i wynika z nadawczego założenia podmiotowości jej odbiorcy. Wyobrażenie osobowego podmiotu nadawczego, który tak a nie inaczej mówi, myśli, ocenia czy reaguje, jest nieredukowalne. Natomiast osobowość wpisanego w wypowiedź odbiorcy, dopóty dopóki on sam nie przejmie roli mówiącego, ma charakter hipotetyczny, pozostając funkcją mowy podmiotu nadawczego.

Ad 2.W dialogu właściwym zetknięcie różnych wypowiedzi ma charakter następczy, wypowiedź po wypowiedzi, dialog nie jest bowiem jedną wypowiedzią, lecz ich przynajmniej dwuogniwowym zespoleniem. Gwarancją tego zespolenia jest zaktualizowana zwrotność relacji „ja” - „ty”. Znaczy to, że odbiorca wypowiedzi jest nie tylko implikowanym, jak w monologu, ale także rzeczywistym podmiotem jej odbioru i stać się może nadawcą następnej wypowiedzi, której odbiorcą uczyni nadawcę wypowiedzi poprzedniej. A zatem, aby powstał dialog, mówiący musi projektować aktualnego odbiorcę jako przyszłego nadawcę, i to takiego, który zdolny będzie przemienić jego samego, mówiącego obecnie, w odbiorcę. Dlatego też: zadaje pytania, stawia warunki, zmusza do zajęcia stanowiska, prowokuje, mówi coś zastanawiającego itp. Programuje w ten sposób replikę, by następnie sam zostać przez nią zaprogramowanym.

Oba wspomniane mechanizmy komunikacyjne, objawione w monologu i w dialogu, regulują warunki uczestniczenia wypowiedzi w relacjach dialogicznych, które ona sama inicjuje, które wraz z nią się nawiązują i wychylone są ku przyszłości. Natomiast mechanizm trzeci - o którym za chwilę - dotyczy dialogowego osadzenia wypowiedzi w tym, co powiedziane wcześniej, zwraca ją ku temu, co dokonane, ku prze s zło ści, stwarzając nową płaszczyznę porozumienia $\mathrm{w}$ aktualnie podejmowanym akcie komunikacyjnym.

Ad 3.W odróżnieniu od właściwej dialogowi sytuacji wypowiedzi po wypowiedzi, sytuacja wypowiedzi w wypowiedzi, czyli sytuacja przytoczenia, jest z istoty swej hierarchiczna. Ustanawia nadrzędność semantyczną wypowiedzi wprowadzającej wobec wprowadzanej. Nawet przy zachowaniu integralności tekstowej przytoczenia, przez samo wyjęcie go z macierzystego 
układu komunikacyjnego i włączenie w układ nowy - jego znaczenie ulega nieuchronnym zmianom. Nieprzebrana jest, znana badaczom, mnogość rozmaitego rodzaju figur przytoczenia, obejmującego wszak wszystkie postacie tekstowych nawiązań między wypowiedziami (od cytatu poczynając, a na trawestacji kończąc). W żadnym jednak z tych przypadków nie następuje równouprawnienie podmiotów tak zestawianych wypowiedzi, chociaż przypominam - aby można było mówić o nawiązanych między nimi relacjach dialogowych, wyczuwalny musi pozostać choć cień ich podmiotowej odrębności.

\section{$*$}

Dialogowa reguła przytoczenia wypowiedzi w wypowiedzi odgrywa szczególną rolę w strukturze utworu literackiego. Hierarchiczna, wielopoziomowa i wielowypowiedzeniowa budowa komunikacyjna utworu daje się bowiem w c ało ści przedstawić jako hierarchia przytoczeń. W pewnym zakresie ta przytoczeniowość była dla badaczy oczywista, o tyle zwłaszcza, o ile dotyczyła relacji między mową bohaterów a mową narratora. Zaakcentować przeto wypada, że stosunek przytoczenia łączy wypowiedzi z wszystkich podmiotowych poziomów utworu. Zhierarchizowanemu układowi podmiotowemu: bohater - narrator (podmiot liryczny) - autorski podmiot utworu (autor wewnętrzny) odpowiada zhierarchizowany przytoczeniowo układ wypowiedzi tych podmiotów: słowa bohatera - narracja (monolog liryczny) - utwór.

Słowa bohatera wchodzą w równorzędne relacje dialogowe ze słowami innych bohaterów, a poza tym podlegają dwustopniowo zhierarchizowanej przytoczeniowej interpretacji dialogicznej: przez włączenie w narrację, a następnie, wspólnie z nią, przez włączenie w utwór. Na każdym stopniu uzyskują inną perspektywę znaczeniową, wprowadzone bowiem zostają w inny układ interpretacyjny.

Rozumienie narracji jako przytoczenia pozwala objaśnić to, co wyczuwa każdy bardziej wnikliwy interpretator: że jej sensy nie są ostatecznymi sensami utworu. Przytoczeniowy status narracji, nie tak narzucający się uwadze, jak przytoczeniowy status mowy bohaterów, a często wręcz zakamuflowany, objawia się najwyraźniej, jeśli porównać właściwą jej sytuację komunikacyjną z sytuacją całego utworu jako tekstu szczególnego rodzaju. Odnoszą się bowiem do niego nie tylko wszystkie reguły literackie zrealizowane na wszystkich poziomach jego wewnętrznej budowy (a więc 
dotyczące zarówno narracji, jak i mowy i działań bohaterów), ale też reguły wynikające ze sposobu jego funkcjonowania - jako tekstu zapisanego, opatrzonego tytułem, podzielonego na rozdziały i akapity, wyposażonego być może także w informacje towarzyszące: przypisy, komentarze, ilustracje itp., o ile są wyrazem autorskiej intencji, nie zaś inwencją wydawcy jako zewnętrznego podmiotu.

Interpretowanie konstrukcji utworu jako układu przytoczeniowego pozwala objaśnić napięcia między wielorakim zróżnicowaniem składających się na utwór wypowiedzi, w tym między ich następczym, linearnym porządkiem, a ich hierarchicznym zespoleniem w semantyczną jedność. Tekst dramatu np. jawi się wówczas wyraziście nie tylko jako łańcuch kolejnych wypowiedzi bohaterów, ale jako jednolite dzieło podmiotu autorskiego.

Każda wypowiedź jako przytoczenie staje się w perspektywie wypowiedzi przytaczającej dokonaną całością, chociaż w obrębie swej pierwotnej sytuacji komunikacyjnej ma swój przebieg, jest układem następczym, nie zawsze semantycznie kompletnym i ukończonym.

Hierarchiczność układu przytoczeniowego decyduje o ostatecznym sensie składających się nań wypowiedzi i o aksjologicznym przesłaniu całego utworu. Pozwala więc np. zinterpretować autorskie stanowisko wobec rozmaitych, nieraz wzajemnie sprzecznych treści ideowych i wartościujących, pojawiających się w utworze. Nie sugestywność i moc perswazyjna tych treści mają znaczenie rozstrzygające, ale ich usytuowanie w porządku przytoczeniowym.

Intensyfikacja procesów wartościowania, choć może zachodzić w obrębie mowy jednopodmiotowej o mniej lub bardziej wyraźnych odniesieniach dialogowych, dokonuje się zwłaszcza na styku wypowiedzi różnych zhierarchizowanych podmiotów. I tak, wypowiedź przytoczona, choćby wyraźnie upodmiotowiona, nie ma mocy polemicznej wobec intencji tego, co kto ją przytacza. Wypowiedź bohatera zdana jest więc na łaskę narratora. Natomiast w perspektywie całego utworu, jeśli narrację traktować jako wypowiedź przytaczaną przez podmiot autorski, pojawia się możliwość dialogowego dystansu wobec narratora i zakwestionowania ostatecznej autorytatywności jego osądów, m.in. na temat bohatera. Wbrew narratorowi to bohater może mieć rację. Jeśli stoi za nim intencja autorska, którą potrafi odczytać odbiorca. 


\section{Glosa terminologiczna}

Cudzysłów (wyrażenie cudzysłowowe), cytat, przytoczenie to różne nazwania wypowiedzi dwupodmiotowej: albo stworzonej nie przez tego, kto do swej mowy ją aktualnie wprowadza, albo też wypowiedzi własnej, pochodzącej z innej niż aktualna sytuacji komunikacyjnej.

Nazwa cudzysłów - uwydatnia odrębność obu podmiotów, wskazuje, że jest to wypowiedź cudza, stworzona kiedy indziej, przez kogoś innego niż podmiot obecnie ją wprowadzający.

Nazwa cy tat - uwydatnia odrębny byt wypowiedzi, która ma swego autora i swoje zakorzenienie komunikacyjne, a obecnie zostaje powtórzona przez kogoś, kto się do niej odwołuje.

Nazwa p rzy to c z e n i e - uwydatnia rolę podmiotu, który z jakichś względów wprowadza do własnej mowy inną wypowiedź.

Różnice znaczeniowe między tymi trzema nazwami nie są dość ostre i w różnych pracach nazwy te bywają używane wymiennie. Niemniej jednak skłonna jestem sądzić, że dla komunikacyjnej teorii wypowiedzi istotny charakter ma przy to cze ni e, gdyż najwyraźniej wskazuje na rolę podmiotu wprowadzającego do swej mowy wypowiedź inną. Natomiast wy raż e n i e cu dz y sło w o w e szczególnie uwydatnia pochodzenie od innego niż mówiący podmiotu, c y tat zaś podkreśla zwłaszcza odrębność przywoływanej wypowiedzi, nie kierując uwagi na okoliczności jej nowego usytuowania.

\section{Post scriptum autorskie 2019}

Tekst ten ${ }^{15}$ przedstawiłam jako referat na XXIII Konferencji Teoretycznoliterackiej w Paszkówce we wrześniu 1988 roku. Uważałam go jednak za nieskończony i postanowiłam opublikować później w książce z następnej konferencji. Wtedy jednak okazało się, że przydział arkuszy papieru na wydanie książki jest okrojony i trzeba zrezygnować z druku części referatów na tejże konferencji wygłoszonych. Współredaktorem tego następnego tomu był Janusz Sławiński i nie wypadało, aby nie zaspokoiwszy oczekiwań aktualnych referentów, zamieszczać tekst z konferencji poprzedniej. Ja zaś straciłam ochotę, by nad nim dalej pracować.

Pozostał więc na zawsze w tej niedopracowanej formie. Jego część końcowa to nie wywód ciągły, ale różne dyspozycje notatkowe, przeznaczone do dalszego zastanowienia i rozwinięcia. Obecnie ułożyłam je i przepisałam w myślowej

15 Zatytułowany początkowo Intertekstualność i dialogiczność a problemy interpretacji utworu literackiego. 
postaci sprzed lat, nie uzupełniając niczym, nawet przypisem do książki Marii Renaty Mayenowej ${ }^{16}$, której domysły o ikonicznym i cudzysłowowym zarazem charakterze dzieła literackiego były dla mnie, być może, dialogowym bodźcem do krytycznego zastanowienia się nad semantycznym porządkiem, który nazwałam przytoczeniową budową utworu.

Teoretyczny zamysł mego referatu streściłam, odpowiadając listownie na zapytanie Edwarda Balcerzana w listopadzie 1997 roku. Napisałam doń wówczas: „Referat mój tyczy różnic między - tak podobnymi na pozór - teorią intertekstualności i teorią dialogiczności, różnic zasadzających się, moim zdaniem, na fundamencie odmiennego rozumienia roli podmiotu: negacji podmiotowości (intertekstualność) i jej ośrodkowego usytuowania (dialogiczność).

Przyjmując perspektywę podmiotową i dialogową wysunęłam hipotezę objaśniającą mechanizm zhierarchizowanej wielowypowiedzeniowej struktury utworu, jako szczególny układ p rzy to c zeń wypowiedzi różnych podmiotów (np. próbowałam ująć narrację czy monolog liryczny jako wypowiedzi przytaczane przed podmiot utworu, czyli autora wewnętrznego, podobnie jak wypowiedzi bohaterów przytaczane przez narratora). Dopracowywałam w ten sposób konsekwencje moich wcześniejszych pomysłów na temat komunikacyjnej budowy utworu".

Aleksandra Okopień-Sławińska

16 M.R. Mayenowa Poetyka teoretyczna. Zagadnienia języka, wyd. 2 uzup. i popr., Ossolineum, Wrocław 1979. 


\section{Abstract}

ALEKSANDRA OKOPIEŃ-SŁAWIŃSKA

THE INSTITUTE OF LITERARY RESEARCH OF THE POLISH ACADEMY OF SCIENCES (WARSAW)

Intertextuality, Dialogue and the Citation Construction of a Literary Work

This article explores the differences between two apparently similar theories - that of intertextuality and that of dialogism. These differences, Okopień-Sławińska argues, are rooted in different notions of the role of the subject: a negation of subjectivity (intertextuality) and its situatedness (dialogism). Assuming a perspective that is subjective and dialogic, Okopień-Sławińska proposes a hypothesis that sheds light on the mechanism of the hierarchical and multilayered structure of the work, as a specific arrangement of citations of different subjects' statements (e.g. Okopień-Sławińska presents the narrative or lyric monologue as utterances cited by the subject of the work, i.e. the internal author, quite like the characters' utterances quoted by the narrator). Thus Okopień-Sławińska expands on her earlier research on the communicative construction of a literary work.

\section{Keywords}

intertextuality, dialogism, citation, the communicative construction of a literary work 